\title{
A DEMOCRACIA RACIAL REVISITADA ${ }^{1}$
}

\author{
Antonio Sérgio Alfredo Guimarães ${ }^{2}$
}

$\mathrm{E}$

m 1861, o político e escritor colombiano José María Samper publicou, em Paris, o seu Ensayo sobre las revoluciones politicas y la condicion social de las repúblicas colombianas, no qual, entre outras, defendeu a tese de que "a democracia é o governo natural das sociedades mestiças".

Onde as raças permanecem puras, ou se se misturam e formam uma massa homogênea, à medida que todos se sentem igualados pelo sangue, as aspirações dão uma guinada que leva à criação de aristocracias de diferentes gêneros: algumas heroicas ou guerreiras, outras clericais ou monetárias - ou territorial, ou literária. Pelo contrário, nas sociedades resultantes da fusão de raças antagônicas ou profundamente discordantes, ninguém pode reivindicar a força do sangue; ninguém pode reivindicar uma predominância aristocrática que careceria de base e estaria sujeita a reprovação permanente da impureza de origem. Nessas últimas, as instituições devem se apoiar necessariamente no princípio democrático, ou

1 Esta revisitação começou a ser feita durante minha estadia no Center of Latin American Studies da Universidade de Cambridge, como um Simón Bolívar Professor, entre 2016 e 2017, e se completou com a apresentação de uma versão bem preliminar deste texto ao seminário L'anti-racisme entre science et politique: de l'Amérique Latine à l'UNESCO (1920-1960), em Nice, em julho de 2019. Agradeço a Paulina Alberto, George R. Andrews, Kali Argyriadis, Maria Lúcia Pallares-Burke, Peter Burke, João Reis e Peter Wade por comentários feitos ao texto.

2 Professor titular (sênior) do Departamento de Sociologia da Universidade de São Paulo. antonio.sergio@usp.br. 
seja: admitir a inserção de todas as castas, abrir caminhos comuns, cancelar todo antagonismo social, confundir todos os esforços sem qualquer classificação. Do contrário, se isso não ocorrer, vai-se despertar e manter a guerra civil permanente, alimentar o orgulho de um e a inveja de outros, paralisar o desenvolvimento de todas as forças ou anulá-las por sua hostilidade recíproca. Em suma, a democracia é o governo natural das sociedades mestiças. ${ }^{3}$

Para ele, essa forma de governo corresponderia melhor a povos miscigenados - em que não há endogamia de raças ou classes -, enquanto a monarquia se adaptaria melhor a povos de raça pura e classes bem definidas, que poderiam cultivar aristocracias. Samper teorizava, portanto, a relação entre miscigenação - na verdade, a relativa abertura ou fechamento dos grupos sociais por regras de casamento e intercurso - e formas de governo; e associava, através de equivalências, monarquias a autocracias e democracias a repúblicas e federalismo. A iluminar tais associações está o contraste mais nítido entre os estados-nações nas Américas, formados por uma diversidade de raças e castas, ao tornarem-se politicamente independentes dos velhos estados monárquicos europeus e de suas sociedades bem estabelecidas de classes, ordens e pureza de sangue.

A associação entre formas de governo e raças, entre raças e sociedades, e as diferenças entre sociedades aristocráticas e democráticas era algo bastante discutido no século XIX por políticos e intelectuais latino-americanos e norte-americanos. Portanto, quando no século seguinte, em 1936, Gilberto Freyre, em Sobrados e mucambos, retoma as imagens de "aristocracia" e "democracia" para contrastar a rigidez da organização patriarcal com a flexibilidade das relações entre raças, retoma o enquadramento retórico do século anterior. ${ }^{4}$

3 José María Semper, Ensayo sobre las revoluciones políticas y la condición social de las repúblicas colombianas, Paris: Imprenta de E. Thurnot, 1861, pp. 76-77.

4 Escreveu Freyre: “Até o que havia de mais renitentemente aristocrático na organização patriarcal de família, de economia e de cultura foi atingido pelo que sempre houve de contagiosamente democrático ou democratizante e até anarquizante, no amalgamento de raças e culturas e, até certo ponto, de tipos regionais, dando-se uma espécie de despedaçamento das formas mais duras, ou menos plásticas, por excesso de trepidação ou inquietação de conteúdos”. Gilberto Freyre, Sobrados e mucambos, Rio de Janeiro, José Olympio, 1951, p. 355. 
No entanto, ainda que no século XIX e início do XX seja senso comum erudito, na América Latina, que as sociedades mestiças tendem a ser menos aristocráticas e mais democráticas, estávamos muito longe ainda de falar em "democracia racial" em nossos países. Mesmo porque negávamos que raças fossem socialmente importante entre nós. A expressão "democracia racial" se incorporou ao vocabulário político brasileiro apenas nos anos 1930, ao passo que o seu significado corrente se estabeleceu apenas nos anos 1940, em alguns círculos intelectuais e políticos, para tornar-se, nos anos 1950, de uso corrente nos escritos de ciências sociais.

O irônico dessa história é que a noção de democracia racial foi divulgada nos Estados Unidos como um modo de convivência racial próprio do Brasil e da América Latina, que serviria de antídoto ao racismo norte-americano, marcado pela segregação e pelos linchamentos, mas, assim fazendo, procurava justificar a precariedade da democracia na América Latina; era também ironicamente apresentada como solução aos intelectuais negros norte-americanos em luta por igualdade racial, política e econômica, que já conheciam a expressão pelo menos desde $1914 .^{5}$

Neste artigo retomo, mas não sumarizo ou repito, o que já escrevi sobre a cunhagem da expressão, ${ }^{6}$ seus diferentes significados e seu uso político e "científico". O leitor que já o conhece se beneficiará justamente do que acrescento aqui, com base em minha pesquisa recente sobre fontes e personagens norte-americanos que estiveram envolvidos na consolidação do imaginário da democracia racial. Alguns trabalhos recentes procuraram alargar o escopo da investigação para os Estados Unidos ${ }^{7}$

5 Paulina Alberto e Jesse Hoffnung-Garskof, "Racial Democracy and Racial Inclusion", in Alejandro de la Fuente e George Reid Andrews (eds.), Afro-Latin American Studies: an Introduction (Cambridge: Cambridge University Press, 2018), pp. 264-316.

6 Ver a esse respeito os seguintes textos que escrevi: Antonio Sérgio Alfredo Guimarães, "Democracia racial: o ideal, o pacto e o mito", Novos Estudos Cebrap, v. 20, n. 61 (2001), pp. 147-162; Antonio Sérgio Alfredo Guimarães, "Racial democracy", in Jessé Souza e Valter Sinder (eds.), Imagining Brazil (Lanham: Lexington Books, 2005), pp. 119-140; Antonio Sérgio Alfredo Guimarães, "Democracia racial: o ideal, o pacto e o mito", in Antonio Sérgio Alfredo Guimarães, Classes, raças e democracia (São Paulo: Editora 34, 2012), pp. 137-168.

7 Jessica L Graham, Shifting the Meaning of Democracy: Race, Politics, and Culture in the United States and Brazil, Oakland: University of California Press, 2019. 
e para Porto Rico, ${ }^{8}$ e muito me beneficio dessa expansão. Longe de ser um exercício despretensioso e erudito de arqueologia do saber, pretendo mostrar como a democracia racial é uma noção que só faz sentido num determinado contexto histórico, aquele compreendido entre a construção de um ideal, não de política redistributiva, mas de sociabilidade racial (nos anos 1930), e o de denúncia de sua função de ideologia dominante (a partir dos anos 1970), quando o conceito de democracia, na América Latina, passou a ganhar o sentido estrito de representação política igualitária e de usufruto pleno dos direitos de cidadania. "Democracia racial" poderia ser usado como conceito referente à relação entre democracia e raça, como o faz Jessica Graham no livro a que me referi. Preferi, todavia, continuar a usar "democracia racial" como simples expressão verbal e procurar os diferentes significados que os agentes políticos lhe emprestaram em diferentes conjunturas, no intuito de desvendar seus interesses, contextos e intenções.

\section{As bandeiras e a democracia racial}

Começamos a nos aproximar do uso atual da expressão "democracia racial" com os modernistas paulistas. Alguns destes, depois da tentativa de secessão de São Paulo, em 1932, se reagruparam no Movimento Bandeira. Foram eles quem entrelaçaram, em sua empreitada política, duas noções que pareciam distantes.

A primeira, "fraternidade racial", já de uso corrente na Primeira República, datava dos anos 1910-1930, nutrida, primeiro, nos meios negros e depois expandida para o governo Washington Luís. ${ }^{10}$ Menotti Del Picchia" trata tal fraternidade como "democracia étnica". Se a "fraternidade racial" seria uma forma de solidariedade social entre raças,

8 Alberto e Hoffnung-Garskof, "Racial Democracy".

9 Graham, Shifting the Meaning.

10 Paulina Alberto, Terms of Inclusion: Black Intellectuals in Twentieth-Century Brazil, Chapel Hill: University of North Carolina Press, 2011.

11 Ver Menotti Del Picchia, Soluções nacionais, Rio de Janeiro: Livraria José Olympio, 1935, p. 185 apud Maria José Campos, "Versões modernistas da democracia racial em movimento: estudo sobre as trajetórias e as obras de Menotti Del Picchia e Cassiano Ricardo até 1945" (Tese de Doutorado, Universidade de São Paulo, 2007), p. 184. 
irmanadas numa nação, em "democracia étnica" Del Picchia funde democracia (forma política), solidariedade (forma social) e miscigenação de raças demarcadas por fronteiras débeis. A palavra "democracia" ganha, assim, o significado de uma forma de sociabilidade, um modo de convivência social, perdendo quase completamente o seu sentido de forma de governo:

não nos assoberba a questão negra, o 'racialismo autóctone' contra o ádvena, e se possuímos, como absorvedora força de caldeamento essa inata ausência de preconceitos de cor, de credo e de origem - o Brasil surge perante o mundo como a terra feliz que processou, em toda a sua plenitude, a 'democracia étnica', a mais soberba forma, inédita e cristã, da fraternidade humana. ${ }^{12}$

A segunda, atribuída a Cassiano Ricardo, ${ }^{13}$ foi a expressão “democracia racial", utilizada para realçar o papel de liderança da raça branca, europeia, na organização do estado-nação. Para ele, a democracia brasileira teria sido formada a partir da hierarquia intrínseca das qualidades raciais de seus povos componentes. Era a forma de o Movimento Bandeira evitar alinhamento com o comunismo, o integralismo, o caudilhismo, e aproximar-se do Estado Novo. ${ }^{14}$

O uso da palavra "democracia" pelos modernistas paulistas deve-se principalmente ao contexto histórico dos anos 1930 de completa descrença nos ideais da democracia representativa. Naquele período, a igualdade entre os "homens", a liberdade individual, assim como a própria democracia liberal não passariam de mitos políticos. A realidade seria, ao contrário, a desigualdade entre indivíduos, povos e nações, sendo a liberdade julgada necessária apenas para poucos indivíduos e povos mais avançados. Pressionados pelo fascismo (a que Del Picchia se referia como ditadura das elites) e pelo comunismo (a ditadura de uma classe), e reconhecendo o atraso da maior parte das regiões brasileiras

12 Del Picchia, Soluções nacionais, p. 185.

13 Cassiano Ricardo, "O negro do bandeirantismo paulista", Revista do Arquivo Municipal, v. 47 (1938), pp. 5-45 apud Campos, "Versões modernistas", p. 236.

14 Campos, "Versões modernistas", reproduz diversos trechos de Cassiano Ricardo. Ver p. 250 et seq. 
para viver em democracia política, os paulistas buscavam soluções próprias, que evitassem também a ditadura de um só homem, contra a qual se levantaram em $1932 .{ }^{15}$

Decorre dessa circunstância a busca por teorizar outros tipos de democracia, como a étnica ou a racial, considerados mais afins às condições brasileiras. O Brasil teria que encontrar um regime federalista misto que mesclasse ditadura e democracia em suas diferentes regiões, como propõe Del Picchia, ou adequar-se a um novo tipo de democracia que lhe fosse autêntica.

A propaganda do Estado Novo, entre 1937 e 1945, irá se encarregar de consolidar um imaginário nacional em que os ideários de fraternidade racial, democracia étnica e democracia social serão centrais. Seríamos um povo mestiço e, entre nós, preconceitos de cor ou de raça existiriam apenas em esparsas manifestações individuais, mas não seriam impedimentos para a mobilidade social nem para a participação política de pessoas de cor. ${ }^{16}$ No entanto, em que pese a importância dos paulistas na cunhagem da expressão, o imaginário nacional-racial do Estado Novo deve mais a Gilberto Freyre que a qualquer outro autor, como veremos a seguir.

\section{A conexão norte-americana: Ramos e Freyre}

A entrada dos Estados Unidos na Segunda Guerra Mundial sinaliza o seu papel futuro como líder do "mundo livre", conceito consolidado na Guerra Fria que se segue ao conflito armado. A construção de tal liderança passava necessariamente por profunda e ampla mudança de sua política externa. A aproximação com a América do Sul começara, de fato, no governo Hoover (1929-1933), mas ganha premência com o avanço do fascismo na Europa. Para concentrar-se apenas na América Latina, deve-se citar necessariamente dois obstáculos que precisavam ser vencidos: a simpatia de governos e elites latino-americanos, nos anos 1930,

15 Menotti Del Picchia, A revolução paulista: através de um testemunho do gabinete do governador, São Paulo: Cia. Ed. Nacional, 1932.

16 Angela de Castro Gomes, A invenção do trabalhismo, Rio de Janeiro: Ed. Vértice, 1988; Angela de Castro Gomes, "L'histoire du Brésil écrite par l'Estado Novo: democratie raciale contre democratie liberale", Lusotopie, n. 4 (1997), pp. 267-273. 
por regimes totalitários, e o seu desagrado com a segregação racial e a one-drop rule vigentes nos Estados Unidos. Os dois obstáculos eram nutridos, como sói acontecer, por sentimentos de desconfiança mútua e um enorme vazio de intercâmbio cultural.

O desafio de transpor tal vazio foi equacionado de dois modos por Franklin Roosevelt (1933-1945). Primeiro, com a criação do Office of Inter-American Affairs, sob liderança de Nelson Rockefeller, que deslanchou um amplo programa de intercâmbio militar, cultural e comercial e de ajuda social a países da região ${ }^{17}$ e, segundo, em 1938, com a criação, no Departamento de Estado, de uma Division of American Republics, para cuja chefia foi convidado Richard Pattee, que então dirigia o Instituto Hispano-Americano da Universidade de Porto Rico.

A essa altura, Pattee já era um pesquisador muito ativo na rede que reunia cientistas sociais e intelectuais dos Estados Unidos e da América Latina em torno do estudo dos africanismos nas Américas. Essa rede ao mesmo tempo de pesquisa e de política antirracista, interessada na vida social e cultural dos povos negros e de seus descendentes nas Américas, reunia figuras como Melville Herskovits, W. E. B. Du Bois, Arthur Schomburg, Alain Locke, Rüdiger Bilden, Fernando Ortiz, Jean Price-Mars, Arthur Ramos, entre outros, e fora construída a partir de 1935 por troca de cartas, livros e visitas de pesquisa. ${ }^{18}$

Se o interesse acadêmico por Cuba, Porto Rico, Haiti e Suriname foi alavancado e facilitado pela presença militar e política dos Estados

17 Olívia Cunha, "Travel, Ethnography, and Nation in the Writings of Rómulo Lachatañéré and Arthur Ramos", New West Indian Guide, v. 81, n. 3-4 (2007), pp. 219-257; Maria Lúcia Garcia Pallares-Burke, O triunfo do fracasso, São Paulo: Editora Unesp, 2012; Kevin Yelvington, "The Invention of Africa in Latin America and the Caribbean: Political Discourse and Anthropological Practice", in Kevin A. Yelvington (ed.), Afro-Atlantic Dialogues: Anthropology in the Diaspora (Santa Fé: School of American Research Press, 2006), pp. 35-82; Richard Smith, "Érico Veríssimo, a Brazilian Cultural Ambassador in the United States", Revista Tempo, v. 17, n. 34 (2013), pp. 147-173.

18 Herskovits se corresponde com Fernando Ortiz desde 1929 e com Price-Mars desde 1928. Fernando Ortiz entra em contato com Ramos em 14 de março de 1934, pedindo seus livros. Pattee contata Ramos por carta em 15 de dezembro de 1935, por recomendação do secretário da Sociedade Luso-Brasileira, no Rio de Janeiro, pedindo seus livros. Ramos contata Herskovits por carta em 31 dezembro de 1935, enviando seus livros, e este responde em janeiro de 1936. Herskovits contata Pattee em 20 novembro de 1936 pedindo as conferências de Bellegarde publicadas pelo Instituto Hispano-Americano de Puerto Rico. Ramos envia seus livros a Price-Mars em março de 1936. 
Unidos na região, o contexto político na América do Sul, onde se temia a propagação do racismo e imperialismo norte-americanos, nem sempre facilitava o intercâmbio cultural e acadêmico. Mas o fato é que, desde meados dos anos 1930, havia muito interesse nos meios acadêmicos norte-americanos, com a formação dos estudos africanos, em conhecer a vida social e cultural dos negros no Brasil, não apenas a religião afro-brasileira. Havia mesmo certa ansiedade por ter livros didáticos que abastecessem os cursos universitários americanos, preenchendo tal lacuna. Por outro lado, não se pode diminuir o protagonismo de autores latino-americanos, como Nicolás Guillén, Fernando Ortiz e Arthur Ramos, nessa busca de aproximação e diálogo entre si. Faltava-lhes, entretanto, recursos institucionais, algo que os norte-americanos tinham em abundância. ${ }^{19}$

Na história da constituição da "democracia racial" com seu sentido atual, a rede acima referida, principalmente com os seus desdobramentos políticos durante a Guerra, foi fundamental. Maria Lúcia Pallares-Burke ${ }^{20}$ lembra, com propriedade, os esforços de intelectuais como Rüdiger Bilden em divulgar o sistema de relações raciais no Brasil como um "laboratório de civilização" ou como uma "solução" para o racismo através da mestiçagem. Tais ideias, antes expressas internacionalmente como "embranquecimento" por Batista Lacerda ${ }^{21}$ e que deixaram forte

19 A importância dada à publicação de "The Negro in Brazil", de Arthur Ramos, em 1939, reside nesse interesse. Em 1938, Herskovits já manifestava reservas quanto ao conhecimento que se tinha sobre a vida do negro no Brasil, como sugere este trecho de sua correspondência com Richard Pattee: "Encontrei o último livro [de Ramos] na minha mesa quando cheguei em casa, e ele parece ter feito um excelente trabalho com base no material realmente escasso de que dispõe. Não sei se escrevi para você que, depois de escrever vários capítulos do meu próprio livro projetado sobre o Negro do Novo Mundo, cheguei à conclusão de que preferiria esperar alguns anos até ter mais informações" (Carta de Herskovits a Pattee, 7/9/1938, in "Pattee, Richard", 1936-1940, Melville J. Herskovits (1895-1963) Papers, Northwestern University Archives, Box 18, Folder 6, <https://findingaids.library.northwestern.edu/repositories/6/ resources/20>, acessado em 10/5/2020). Pattee concorda com Herskovits, pois responde em 26 de abril de 1939: "Você deve ter visto a tradução do livro de Ramos que publiquei. Embora seja uma introdução muito elementar ao assunto, espero que possa servir a algum objetivo" (Carta de Pattee a Herskovits, 26/4/1939, in "Pattee, Richard", 1936-1940, op. cit.). A reação dos brasilianistas é a mesma: veja-se Donald Pierson, "Book Review: The Negro in Brazil by Arthur Ramos", American Journal of Sociology, v. 46, n. 2 (1940), p. 267.

20 Pallares-Burke, $O$ triunfo, p. 198.

21 Lilia Moritz Schwarcz, O espetáculo das raças: cientistas, instituições e questão racial no Brasil, 1870-1930, São Paulo: Companhia das Letras, 1993. 
impressão em Du Bois, ${ }^{22}$ ganham novos adeptos entre os liberais norte-americanos, fossem brancos, judeus ou negros.

Há de se lembrar também que, concomitantemente, os nacionalistas mexicanos já haviam forjado o imaginário da nação mestiça ${ }^{23} \mathrm{e}$ de raça cósmica ${ }^{24}$ justamente para se contraporem ao racismo norte-americano. ${ }^{25}$ Os mexicanos, entretanto, buscaram sua referência para a nação mestiça na romantização da glória dos antigos impérios asteca, maia e inca. A escravidão negra no México e seu legado foram praticamente apagados desse imaginário. Os brasileiros, ao contrário, achavam não ter um problema indígena, mas sim um potencial problema racial e nacional com a enorme miscigenação entre brancos e negros. A democracia racial refere-se a esse sentimento de que a absorção de milhões de africanos escravizados trazidos para o Brasil ao longo de três séculos representava um problema.

Fundamental, sem dúvida, para o diálogo com os Estados Unidos foi a recepção das ideias de Gilberto Freyre, principalmente sua influência sobre a historiografia da escravidão nas Américas, através de Frank Tannenbaum. ${ }^{26}$ Participando, ainda que marginalmente, da rede tecida por Herskovits, mas com voo próprio, circularam internacionalmente as ideias e os ideais expressos em Casa-Grande \& Senzala. Freyre foi o principal cientista social e historiador a propagar a imagem do Brasil como locus de um sistema de relações raciais peculiar, marcado pela ausência de preconceitos raciais sistemáticos, ou seja, alicerçados em instituições sociais e jurídicas; pela ausência de uma linha de cor que impedisse a mobilidade social; por relações sociais fraternas entre brancos e negros; e pela miscigenação biológica e cultural intensa. Nos Estados Unidos, as ideias de Freyre já circulavam academicamente, em conferências

22 William Edward Burghardt Du Bois, "Brazil", in David J. Hellwig (ed.), African American Reflections on Brazil's Racial Paradise (Philadelphia: Temple University Press, 1992), pp. 31-34.

23 Manuel Gamio, Forjando patria (pro-nacionalismo), México: Porrúa Hermanos, 1916.

24 José Vasconcelos, La raza cósmica: misión de la raza iberoamericana: notas de viajes a la América del Sur, Madrid: Agencia Mundial de Librería, 1925.

25 Juliet Hooker, Theorizing Race in the Americas: Douglass, Sarmiento, Du Bois, and Vasconcelos, Oxford: Oxford University Press, 2017.

26 Anthony John R. Russell-Wood, The Black Man in Slavery and Freedom in Colonial Brazil, New York: St. Martin's Press, 1982. 
públicas, antes da publicação de seu primeiro livro em inglês, escrito especialmente para o público norte-americano, graças à atuação de Pattee no Departamento de Estado. ${ }^{27}$

Mas Gilberto chamava esse padrão de relações raciais de "democracia social" e "democracia étnica". Por que afinal prevaleceu a expressão "democracia racial", que, como vimos, estava associada, no Brasil, à visão racialmente hierárquica de Cassiano Ricardo? A resposta a essa pergunta se encontra muito provavelmente na conexão norte-americana, na rede africanista já referida e na circulação de intelectuais brasileiros nos meios negros norte-americanos, veiculando o modo como a geração brasileira dos anos 1930 imaginava o Brasil.

De fato, entre os africano-americanos, desde pelo menos 1914, era corrente, ainda que não proeminente, o uso da expressão "racial democracy". No começo do século XX, a expressão ainda era usada em contraste com a aristocracia, como no resto das Américas. Assim, The Crisis, a revista dirigida por W. E. B. Du Bois, republica em 1914 um artigo assinado pelo jornalista branco americano Ray Stannard Baker em que se lê:

Uma posição pela aristocracia racial significa guerra, ódio, exclusividade árida e, finalmente, degeneração e fracasso: uma posição pela democracia racial e fraternidade significa amor no mundo, amizade, sacrifício, nova fertilidade, uma busca mais ampla pela fé e triunfo final. Os indivíduos podem sofrer no processo, as nações podem perecer, mas a civilização, o reino da humanidade, crescerá, ficará mais bonita. ${ }^{28}$

27 Gilberto Freyre, Brazil: an Interpretation, New York: Alfred A. Knopf, 1945. Escreveu Richard Smith, "Érico Veríssimo", p. 150: "Veríssimo foi o primeiro beneficiário brasileiro do Leader Grant do Departamento de Estado dos EUA. Entre as centenas de brasileiros trazidos para os Estados Unidos entre 1941 e 1945 estavam o antropólogo Gilberto Freyre, o historiador Sérgio Buarque de Holanda, o historiador e romancista Vianna Moog, o jornalista e romancista Orígenes Lessa".

28 Ray Stannard Baker, "The Burden of Being White”, The Crisis, New York, abr. 1915, pp. 27980. O artigo foi publicado originalmente na American Magazine (1914). Ray Stannard Baker, que assinava também como David Grayson, ganhou o prêmio Pulitzer de biografia em 1940. Esse artigo foi citado por Alberto e Hoffnung-Garskof, "Racial Democracy". 
Mas, para os negros dos Estados Unidos, o ideal de democracia política deveria, para ser efetivo, incluir igualdade de oportunidades e de tratamento entre as raças que compunham a nação americana. Não foram, portanto, intelectuais brancos, mas os negros os primeiros a reivindicar a democracia social e racial. Os judeus foram seus grandes aliados. No começo dos anos 1940, o termo "democracia racial", ainda que menos utilizado que outras expressões, tais como "racial equality" ou "racial justice", já circulava nos Estados Unidos com seu sentido atual de igualdade política, social, econômica e cultural entre brancos e negros, sem qualquer conotação, seja de fraternidade, seja de miscibilidade. Pode-se encontrá-lo, por exemplo, no famoso An American Dilemma, de Gunnar Myrdal. ${ }^{29}$ Será consagrado com esse sentido na academia norte-americana por autores clássicos da sociologia das relações raciais. ${ }^{30}$

O termo aparece, por exemplo, nas páginas de The Journal of Negro Education, que em seu número temático sobre "Racial Minorities and the Present International Crisis", de julho de 1941, traz artigos de Arthur Ramos ${ }^{31}$ e Gilberto Freyre. ${ }^{32}$ A tensão, nos anos 1940, entre o que significava democracia racial para Ramos e democracia social e étnica para Freyre, de um lado, e a democracia racial buscada pelos intelectuais negros norte-americanos é evidente nas páginas daquela revista. Os norte-americanos salientavam unicamente a liberdade e igualdade de tratamento e de oportunidades, numa ordem política democrática, enquanto os brasileiros enfatizavam a amistosidade das relações raciais e negavam a existência de preconceitos puramente raciais no Brasil.

Ramos, em seu artigo, emprega a expressão como um conceito-senha, a fazer a ponte entre democracia como política e direitos, tal como usada pelos negros norte-americanos, por um lado, e democracia como sociabilidade (mestiçagem e ausência de preconceitos fortes), por

29 Gunnar Myrdal, An American Dilemma: the Negro Problem and Modern Democracy, New York: Harper \& Brothers, 1944, p. 648.

30 Michael Omi e Howard Winant, Racial Formation in the United States: from the 1960s to the 1980s, New York: Routledge \& Kegan Paul, 1983.

31 Arthur Ramos, “The Negro in Brazil”, The Journal of Negro Education, v. 10, n. 3 (1941), pp. 515-523.

32 Gilberto Freyre, "Brazil and the International Crisis", The Journal of Negro Education, v. 10, n. 3 (1941), pp. 510-514. 
outro. ${ }^{33}$ Segundo sua argumentação, a democracia, como forma política, não poderia ser pensada fora de seu significado cultural. ${ }^{34}$ Freyre, por seu turno, critica duramente o comportamento segregacionista dos anglo-saxões e nega, devido à "democracia" que teria regulado desde o Império as relações entre brancos e pretos no Brasil, que se possa definir sociologicamente uma raça negra no Brasil. ${ }^{35}$ Os norte-americanos, ao contrário, reafirmam a visão de uma democracia representativa que reconheça plenamente os direitos dos negros enquanto raça ${ }^{36}$ Assim, temos os brasileiros defendendo a factual inexistência de raças no plano social, e os americanos pedindo o seu pleno reconhecimento civil e desenvolvimento econômico. Mas as evidências são de que as lideranças negras americanas acreditavam que realmente os negros brasileiros viviam uma situação de maior igualdade. ${ }^{37} \mathrm{Ou}$ seja, falar de democracia racial naquele momento não deixava de soar como um canto de sereia aos ouvidos americanos. ${ }^{38}$

No esforço dos Estados Unidos de trazer os países sul-americanos para sua área de influência cultural, contrapondo-se à influência fascista e comunista na América Latina ${ }^{39}$, tal rede será mobilizada e ativada para

33 Escreve Ramos, "The Negro in Brazil", p. 522: "No Brasil, temos uma das mais puras democracias raciais do hemisfério ocidental".

34 Diz ainda: "Quanto às democracias políticas, elas não passam de uma superestrutura que repousa nas realidades essenciais de cada cultura. É preferível não colocar esse problema racial em termos do futuro da democracia política do mundo, mas em termos da filosofia de cada país no tratamento das raças". Ramos, "The Negro in Brazil”, p. 522.

35 Gilberto Freyre escreve em "Brazil and the International Crisis", p. 512: "Assim, eles são mais conscientes da classe do que da raça. Eles são mais uma classe negra do que uma raça negra".

36 Quando o sociólogo negro Charles Johnson compara democracia a totalitarismo, escreve: “A implicação sutil do totalitarismo é que uma hegemonia racial ou de classe, em vez do ideal de igualdade democrática, governará o estado corporativo". Charles S. Johnson, "The Negro and the Present Crisis", The Journal of Negro Education, v. 10, n. 3 (1941), p. 593.

37 Como escreveu William Pickens, presidente da National Association for the Advancement of Colored People (NAACP), em 1940, apresentando Rüdiger Bilden e Arthur Ramos ao reverendo Frank Twine: "Talvez o negro brasileiro usufrua de maior igualdade no meio da população em que vive do que qualquer negro de qualquer estado americano". Ver Pallares-Burke, $O$ triunfo. p. 285.

38 No artigo já referido, Johnson ecoa os mesmos valores de Freyre e Ramos ao mencionar os regimes fascistas: "Seus princípios não contêm pretensão de igualdade, fraternidade, liberdade, iniciativa livre ou amor fraterno. Por mais vazias que essas frases possam nos parecer, elas têm sido os ideais que impedem a fixação de linhas que limitam permanentemente as oportunidades por causa de raça, cor, credo ou classe". Johnson, "The Negro", pp. 593-594.

Graham, Shifting the Meaning. 
discussão de políticas para a saída da crise das democracias ocidentais. É preciso lembrar que os comunistas sempre foram muito críticos do racismo norte-americano e apresentavam ao mundo a União Soviética como um país igualitário, sem preconceitos raciais, de gênero ou de classe. Por outro lado, a política norte-americana do big stick, com intervenções militares rotineiras no Caribe e na América Central, afastava defensivamente os grandes países latino-americanos de sua área de influência, como que para garantir sua autonomia política e cultural, a começar pelo México.

A estadia de Arthur Ramos nos Estados Unidos nos anos $1940 \mathrm{fez}$ parte dessa política de aproximação. Richard Pattee - apesar da notória diferença ideológica com Ramos ${ }^{40}$ - será, junto com Herskovits, o patrono de sua inserção política e institucional nos anos pós-guerra, o que garantirá ao antropólogo alagoano, formado na Escola de Medicina da Bahia, renome internacional. Sabemos que Ramos, depois de seu retorno ao Brasil, publicará uma série de artigos políticos, que engajam a antropologia na luta contra o racismo e na reconstrução democrática do pós-guerra. Tal militância levará Ramos, posteriormente, à direção do Departamento de Ciências Sociais da Organização das Nações Unidas para a Educação, a Ciência e a Cultura (Unesco), que patrocinará os famosos estudos de relações raciais no Brasil, nos anos 1950, quando a democracia racial brasileira será apresentada ao mundo. ${ }^{41}$

As atividades políticas de Ramos nos Estados Unidos, vale a pena lembrar, começaram com a Onwentsia Conference, em abril de 1941, quando foi convidado por uma organização chamada World Citizens Association para participar de uma reunião de expertos em relações

40 Enquanto Ramos era acusado durante o Estado Novo de ligação com o Partido Comunista, Pattee foi sempre um católico fervoroso e conservador. Sobre Ramos, ver Luitgarde Oliveira Cavalcanti Barros, Arthur Ramos e as dinâmicas sociais de seu tempo, Maceió: Edufal, 2000, p. 142.

41 "O Brasil é renomado mundialmente por sua democracia racial”, escrevia Wagley, em 1952, na "Introdução" ao primeiro volume de uma série de estudos sobre relações entre negros e brancos no Brasil, patrocinados pela Unesco. Charles Wagley (org.), Race and Class in Rural Brazil, New York: Columbia University Press, 1952, p. 7. 
internacionais, em Lake Forest, Illinois, não muito distante de Evanston. Suas falas nessa conferência estão publicadas em inglês ${ }^{42}$ e em português. $^{43}$

Como Freyre já fizera em suas conferências na Europa, ${ }^{44}$ Ramos salientou a formação da cultura e da personalidade brasileiras, em detrimento das formas políticas, para definir a democracia. Do mesmo modo que Freyre, Ramos também se refere ao Brasil como "democracia", no que pese estarmos, naquele momento, sob o jugo de uma ditadura. Ramos utilizava, portanto, a expressão "democracia racial" com o mesmo sentido com que Freyre empregava a expressão "democracia social" ou "democracia étnica", confundindo-a deliberadamente com a expressão usada ocasionalmente pelos negros norte-americanos. Assim como Freyre, Arthur Ramos pretendia transformar a miscigenação cultural e biológica, que caracterizaria o Brasil, em marco fundador do mundo pós-racista que se avizinhava. Mas, em artigo sobre o preconceito racial na América Latina, é sintomático que Pattee, ${ }^{45}$ muito mais enfronhado no meio negro norte-americano, não utilize a expressão “democracia racial” para se referir às sociedades da América Latina, mas sim o termo freyriano "democracia social". Estas seriam sociedades sem racismo, mas onde se praticavam preconceitos raciais em graus variados.

Assim como Freyre, Ramos mantinha contatos regulares com os líderes afro-brasileiros, no Rio de Janeiro e em São Paulo, sendo grande o seu prestígio nesse meio. Sabemos que foi, por exemplo, convidado por Francisco Lucrécio, em setembro de 1936, para proferir conferência comemorativa do quinto aniversário da Frente Negra Brasileira (FNB) e que visitou sua sede em São Paulo, em 1935. De fato, seu pensamento

42 "O professor Ramos pediu ao conferencista que definisse para ele seu conceito de democracia, porque em tais assuntos é preciso distinguir entre vários conceitos, democracia política, social, racial e religiosa. 'Não sei', disse ele, 'o que é a democracia'. O que é importante é a influência do ambiente cultural na personalidade, e não no contexto político. 'No Brasil, temos um exemplo interessante; mesmo quando você tem tentativas de governo pessoal, como é comum nos países da América do Sul, é impossível que o governo vá contra a tradição de liberdade cultural e religião"'. World Citizens Association. The World's Destiny and the United States: a Conference of Experts in International Relations, Chicago: WCA, 1941, pp. 272-273.

43 Arthur Ramos, Guerra e relações de raça, Rio de Janeiro: Gráfica Perfecta, 1943.

44 Gilberto Freyre, Conferências na Europa, Rio de Janeiro: Ministério da Educação e Saúde, 1938.

45 Richard Pattee, "Race Prejudice in Latin America", The Crisis, v. 51, n. 402 (1944), pp. 195-197. 
influenciou muitos ativistas negros, e suas ideias só perderão importância com a ascensão de uma nova leva de intelectuais negros, liderada por Guerreiro Ramos, ${ }^{46}$ assim como, nas ciências sociais, uma nova geração se encarregará de sepultar os estudos culturalistas. ${ }^{47}$

A expressão "democracia racial" que Ramos utilizou é sinônima da "democracia étnica ou social" de Freyre e passou a ser uma reivindicação dos negros brasileiros até pelo menos 1964. O prestígio de Ramos nos meios negros pode ser avaliado pelas palavras que Abdias do Nascimento reservará ao cientista alagoano, lembrando sua participação na Conferência Nacional do Negro, em 1949:

Ainda nesta mesma sessão de encerramento, pronunciaria talvez, uma de suas últimas palestras públicas, o Professor Arthur Ramos, antes de seguir para assumir em Paris o cargo de Diretor do Departamento de Ciências Sociais da UNESCO, onde faleceu. Foi uma aula notável o seu discurso de encerramento. ${ }^{48}$

\section{Richard Pattee}

A trajetória de Richard F. Pattee merece uma seção à parte. Nasceu em 1906, no Arizona, segundo Smith, ${ }^{49}$ ou em Montana, em abril de 1906, segundo Martins..$^{50} \mathrm{O}$ certo é que foi criado no Arizona, onde fez a maior parte de sua vida escolar, graduando-se em 1926. Membro da irmandade Phi Delta Theta, é no jornal dessa irmandade que encontramos uma primeira biografia de Richard Pattee. ${ }^{51}$ Aprendemos com Lawson Smith que ele se bacharelou pela Universidade do Arizona em 1926, fez mestrado

46 Alberto Guerreiro Ramos, Introdução crítica à sociologia brasileira, Rio de Janeiro: Editorial Andes, 1957.

47 Mariza Corrêa, As ilusões da liberdade: a Escola Nina Rodrigues e a antropologia no Brasil, Bragança Paulista: Universidade São Francisco, 1998.

48 Abdias Nascimento, O negro revoltado, Rio de Janeiro: Edições GRD, 1968, p. 43.

49 Richard Smith, "Érico Veríssimo".

50 Alfredo Nascimento Martins, Discurso no doutoramento solene do doutor Richard Pattee pela Faculdade de Letras da Universidade de Coimbra, Coimbra: Imprensa de Coimbra, 1965.

51 Lawson V. Smith, “Arizona Phi Becomes”, The Scroll of Phi Delta Theta, v. 58, n. 1 (1933), pp. 144-145. 
em história na Universidade Católica da América, em Washington, entre 1926 e 1927, e foi contratado como professor da Universidade de Porto Rico para o ano letivo de 1927-1928. No seu último ano na Universidade do Arizona, "ele organizou uma turnê de debate que o levou, junto com dois companheiros de turma, em quase todas as seções [da Phi Delta Theta] dos Estados Unidos e até de Porto Rico". ${ }^{52}$ Em 1928, durante o recesso do Natal, conheceu Santo Domingo e Haiti, e findo o ano letivo em Porto Rico, viajou para a Europa (Inglaterra, França, Espanha e Portugal), chegando a tomar aulas de verão na Universidade de Coimbra. Em 1929, escreve Lawson Smith: "Tendo obtido licença da Universidade de Porto Rico, o irmão Pattee decidiu fazer uma verdadeira turnê pela América do Sul. Durante o verão de 1929, ele tomou um navio para o Rio de Janeiro, Brasil. De lá seguiu para o norte, visitando Vitória, Bahia, Pernambuco, Ceará, Maranhão e Pará" ${ }^{53} \mathrm{O}$ fato é que Pattee, depois do Brasil, viajou por quase toda a América do Sul, em 1929, da Bolívia até Buenos Aires, voltando depois a Porto Rico como professor, ao mesmo tempo que cursava doutorado em história na mesma instituição.

Richard Pattee se estabeleceu em Porto Rico, em parte atraído pela cultura católica latino-americana e certamente por seu amor pela língua espanhola e portuguesa. Mas é também provável que Pattee tenha sido atraído pelo esforço da administração Roosevelt em recrutar jovens professores norte-americanos para a Universidade de Porto Rico. De fato, em 1931, o governador de Porto Rico nomeado pelos EUA, Theodore Roosevelt Jr. nomeou o doutor Carlos E. Chardón como chanceler da Universidade de Porto Rico. A gestão de Chardón sofreu a resistência dos estudantes nacionalistas porto-riquenhos e foi o estopim do massacre de Rio Piedras, em 24 de outubro de 1935, quando estudantes foram assassinados pela polícia colonial, chamada pelo reitor para defender a integridade da universidade. ${ }^{54}$ Richard Pattee, sabemos também, dirigiu a comissão da Universidade de Porto Rico que visitou Roosevelt em 1935 (ver Figura 1).

53 Smith, "Arizona Phi Becomes", p. 144.

54 Delma S. Arrigoitia, Puerto Rico por Encima de Todo: Vida y Obra de Antonio R. Barcelo, 1868-1938, San Juan: Ediciones Puerto, 2008. 
Figura 1 - O presidente Roosevelt recebe membros da Comissão da Universidade de Porto Rico no escritório executivo da Casa Branca. A partir da esquerda: presidente Roosevelt; Carlos Chardon, reitor; Richard Pattee, professor de história e presidente da comissão; Otto Riefkohl, Arturo Morales Carrion e Francisco Ponsa Feliu, membros da comissão.

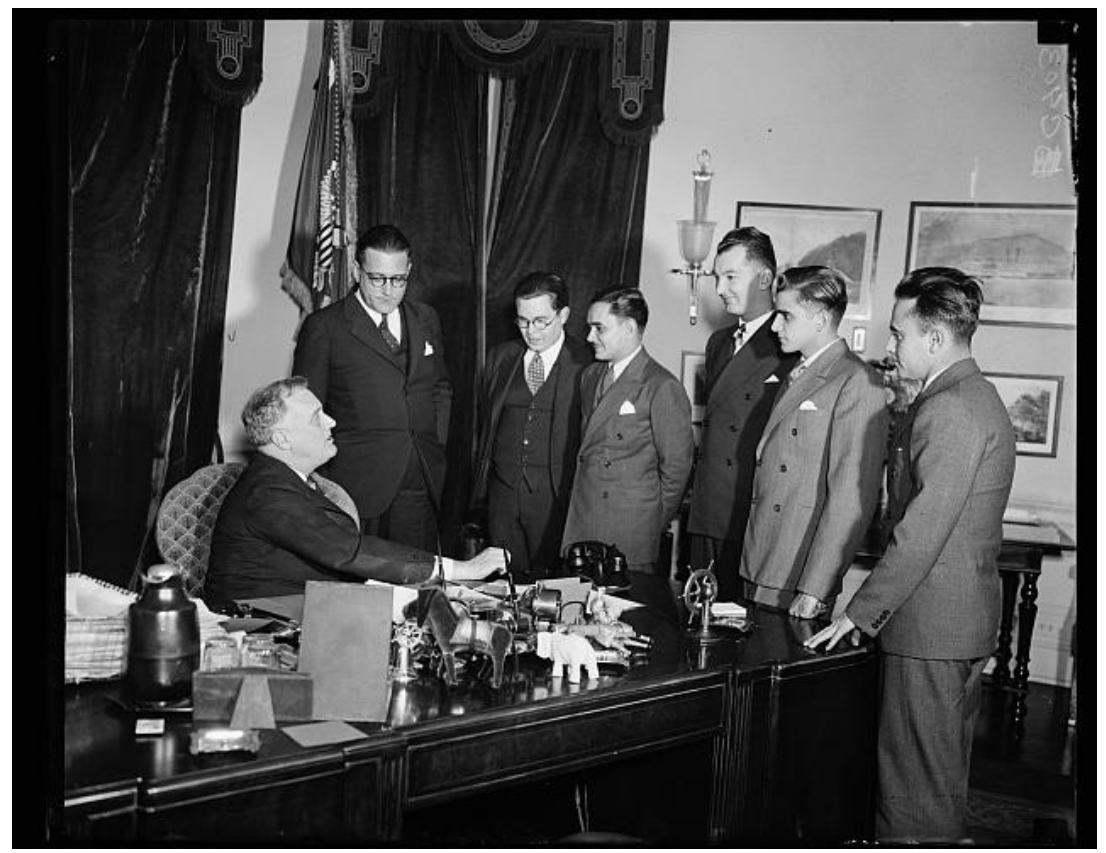

Fonte: Library of Congress. ${ }^{55}$

No mesmo ano de 1935, Richard Pattee já entretinha uma relação profissional com Arthur Schomburg, ${ }^{56}$ passando a frequentar os meios negros do Harlem, chegando mesmo a colaborar com o jornal negro The Crisis, criado por Du Bois. ${ }^{57}$ Sua relação com Du Bois passa pelo projeto da Encyclopedia of the Negro, que este organizava com outros intelectuais africano-americanos. ${ }^{58}$ Pattee tem a ambição, como historiador, nessa

55 "President greets Puerto Rican debaters", Library of Congress, $<$ http://loc.gov/pictures/ resource/hec.47089/>, acessado em 20/05/2020.

56 Pallares-Burke, $O$ triunfo.

57 Richard Pattee, "Book Review Cannibal Cousins by John R. Cruige", The Crisis, v. 42, n. 7 (1935), p. 218; Pattee, "Race Prejudice".

58 Em 1936, Rayford Logan pede a Pattee para fazer contato com intelectuais latino-americanos 
época, de estudar os negros do Haiti e de Porto Rico à maneira que faziam Fernando Ortiz com Cuba e Price-Mars com o Haiti. Por isso, já entrara em contato com Arthur Ramos. Quem lhe indicou Ramos foi o secretário da Sociedade Luso-Africana do Rio de Janeiro (SLARJ), com quem já se correspondia à época, ligado que estava à rede de católicos latino-americanos. A sociedade, que tinha por lema "Pela raça, pela língua", defendia a excelência do imperialismo português vis-à-vis outros imperialismos. Pattee, de formação católica e conservadora, era - desde meados dos anos 1930 - um admirador de Salazar e da civilização luso-brasileira exaltada por Gilberto Freyre, fartamente reconhecida pela SLARJ.

Em carta que dirige a Ramos, em 15 de dezembro de $1935,{ }^{59}$ Pattee pede que lhe envie exemplares de $O$ negro brasileiro e $O$ folclore negro no Brasil, prometendo-lhe, em troca, resenhar esses livros para o Hispanic American Historic Review e ocasionalmente incorporar o conhecimento neles adquirido em artigos no The Crisis. Pede, finalmente, indicação de obras e de autores brasileiros nas áreas de estudos africanistas. Suas conexões em 1935 incluíam, portanto: Schomburg e, através deste, os intelectuais de Nova York ligados à National Association for the Advancement of Colored People (NAACP); a conexão católica conservadora na América Latina; e já colaborava também com Price-Mars, de quem traduzira para o inglês Ainsi Parla l'Oncle. É provável que, em dezembro de 1935, Pattee ainda não tivesse contato com Melville Herskovits, mas isso seria feito pouco tempo depois, ainda em 1936. De fato, em dezembro de 1936, quando Pattee já ocupava o cargo de diretor do Instituto Ibero-Americano da Universidade de Porto Rico, Herskovits lhe escreve pedindo cópia das palestras feitas naquele instituto por Dantès Bellegarde. ${ }^{60}$

que pudessem colaborar com a enciclopédia. Carta de Rayford W. Logan a Pattee, 12/11/1936, W. E. B. Du Bois Papers, Special Collections and University Archives, University of Massachusetts Amherst Libraries, MS 312. Ver também: Carta de Pattee a Du Bois, 05/04/1937, Du Bois Archives, Correspondence, reel 47, fl. 978.

59 Carta de Pattee a Ramos, 15/12/1935, Biblioteca Nacional, Coleção Arthur Ramos, Manuscritos, I-35,36,2034, <http://objdigital.bn.br/acervo_digital/div_manuscritos/mss1299490.pdf>, acessado em 20/05/2020.

60 Carta de Herskovits a Pattee, 20/11/1936, in "Pattee, Richard", 1936-1940, op. cit. 
Através de Ramos, provavelmente, Pattee é convidado a enviar uma comunicação ao Congresso Afro-Brasileiro da Bahia, em 1937, dirigido por Edison Carneiro e Aydano Ferraz. A essa altura, sua nomeada já está estabelecida no campo dos estudos africanistas, a crer nos jovens organizadores do Congresso, que escrevem na apresentação do livro em que reuniram as comunicações: "as referências feitas ao Congresso por um Rüdiger Bilden, um Fernando Ortiz, um Reuter, um Charles Johnson, um Robert Park, um Richard Pattee, um Henri Wallon, uma Maria Archeer, foram as mais encorajadoras para os moços que assumiram a responsabilidade da sua realização". ${ }^{61}$ Tal nomeada, no entanto, talvez se deva menos à sua produção científica no campo afro-americanista e mais à sua nova posição política. Agora Pattee era não apenas um professor em Porto Rico, pois que, em 1938, aceitara dirigir a Divisão Cultural para as Américas do Departamento de Estado dos EUA, cargo que deixou apenas em 1943.

A tradução abreviada de O negro brasileiro, de Arthur Ramos, foi publicada por Pattee em 1939, com a colaboração de Melville Herskovits, Arthur Schomburg, Carter G. Woodson e Rüdiger Bilden. Este último também intermedeia o contato de brasileiros com o meio intelectual negro do Harlem e de Washington. ${ }^{62}$ A partir de 1938, Pattee, já no Departamento de Estado, amplia bastante seu envolvimento nos meios negros norte-americanos e intensifica sua intermediação com os estudiosos latino-americanos. Um exemplo de sua interação e penetração no mundo latino-americano é a publicação em português, em 1940, pela Revista do Instituto Histórico e Geográfico do Rio Grande do Sul, de três ensaios seus sobre intelectuais e políticos latino-americanos - Oliveira Lima, Jean-Jacques Dessalines e Gabriel Garcia Moreno - traduzidos do espanhol, língua em que foram originalmente publicados entre 1936 e 1939.

Pattee, todavia, nunca demonstrou interesse especial pela noção de democracia étnica ou racial de Freyre ou Ramos; seu interesse parece ter-se limitado exclusivamente a pôr esses intelectuais em diálogo com

61 Edison Carneiro e Aydano do Couto Ferraz. "Congresso Afro-Brasileiro da Bahia", in O negro no Brasil: trabalhos apresentados ao $2^{\circ}$ Congresso Afro-Brasileiro (Bahia) (Rio de Janeiro: Civilização Brasileira, 1940), p. 8.

62 Ver Pallares-Burke, $O$ triunfo, p. 251. 
o mundo intelectual afro-americano. Não está claro para mim quando Pattee se encontra pela primeira vez pessoalmente com Freyre, mas, pela parca correspondência que encontrei entre os dois (sete cartas), parece que essa relação foi apenas profissional e se iniciou quando Pattee já estava no Departamento de Estado. Há entre eles amigos em comum, como Rüdiger Bilden e Lewis Hanke, e o interesse de Pattee em ver traduzido para o inglês Casa-Grande \& Senzala. Das sete cartas, uma Freyre recebeu pessoalmente das mãos de Franklin Frazier, em 1940, quando este visitou o Recife durante sua pesquisa de campo no Brasil; antes dela, em 1939, Pattee lhe escrevera para enviar seu estudo sobre Oliveira Lima, de quem fora aluno em Washington; em outra, lamenta não tê-lo encontrado durante sua visita aos EUA; enfim, trata de assuntos prosaicos. Nas demais cartas, Pattee discute a participação futura de Freyre em uma possível conferência de estudos afro-americanistas a ser realizada em Porto Príncipe, em 1941.

\section{The Crisis e o meio intelectual negro nos Estados Unidos}

Vale a pena, antes de continuar esta narrativa, desenvolver um pouco mais o modo como o Brasil era visto antes e passou a ser visto durante o esforço de guerra americano dos anos 1940, pois isso nos ajudará a entender o diálogo estabelecido entre a intelectualidade brasileira e o mundo negro norte-americano. Restringir-me-ei aqui a apenas uma fonte, o jornal The Crisis, examinando o período compreendido entre 1935 e $1945 .^{63}$

The Crisis foi fundado em 1910 por W. E. B. Du Bois e outros intelectuais negros americanos como publicação oficial da NAACP. Uma busca nos seus arquivos on-line ${ }^{64}$ revela o modo como o Brasil era apreendido e utilizado pela parcela mais progressista dos negros norte-americanos, justamente aqueles com quem Richard Pattee procurou se

63 Para uma visão de maior escopo temporal, o leitor deve consultar David J. Hellwig (ed.), African American Reflections on Brazil's Racial Paradise, Philadelphia: Temple University Press, 1992; George R. Andrews, "Visões afro-americanas sobre o Brasil, 1900-2000", Revista de Ciências Sociais, v. 48, n. 2 (2017), pp. 20-52; Flávio Thales Ribeiro Francisco, O novo negro na diáspora: modernidade afro-americana e as representações sobre o Brasil e a França no jornal Chicago Defender (1916-1940), São Paulo: Intermeios, 2016.

64 The Crisis, New York, <https://books.google.com.br/books?id=5FoEAAAAMBAJ\&hl=pt-BR\&source $=$ gbs_all_issues_r\&cad=1>, acessado em 23/4/2020. 
envolver durante o período em que investiu numa carreira de historiador afro-americanista.

Visto cronologicamente, no começo dos anos 1930, o desconhecimento sobre o Brasil era enorme nos Estados Unidos. Por exemplo, num artigo sobre revoltas escravas, Stanley Rappeport ${ }^{65}$ escreve: "Em um país como o Brasil, onde não havia lugar para onde fugir e se contava com pouca ou nenhuma simpatia dos brancos, o único método possível de combater a servidão era por insurreição". Esse desconhecimento era, entretanto, favorável ao florescimento da ideia mítica do Brasil como terra da igualdade social e racial. Em janeiro de 1937, The Crisis reproduz o editorial do Courier, de Pittsburgh, em que se encontra a velha imagem de Frederick Douglas sobre o país: "Isso porque há uma igualdade social absoluta no Brasil, que é, junto com a Rússia, a maior democracia no mundo". ${ }^{66}$ Destaco outra frase para salientar tal desconhecimento: "Desde 1886 [sic] os escravos brasileiros foram emancipados. Como todo homem livre, o liberto se recusou a cultivar as antigas plantações escravagistas, e assim o Brasil perdeu sua liderança na produção de cana-de-açúcar e borracha para Cuba e as Índias Orientais Holandesas". ${ }^{67}$

Entretanto, já em 1938, com o advento do nazifascismo na Europa, informações mais realistas começam a chegar à opinião pública negra norte-americana sobre o que estava em jogo na América Latina. Escreve Harold Preece, em artigo intitulado "A Labor Boycott for Peace", citando R. A. Martinez (The New Masses): “O que está acontecendo no Brasil tem acontecido em menor grau em toda a América Latina. Que a maioria desses países tenha se alinhado ao bloco internacional fascista em anos recentes não é nenhum acidente" ${ }^{68} \mathrm{O}$ artigo de Preece procura justamente combater a política de neutralidade dos Estados Unidos e denunciar seu afastamento dos vizinhos latino-americanos.

65 Stanley Rappeport, “Slave Struggles for Freedom”, The Crisis, New York, set. 1936, p. 265.

66 "Editorial of the Month: 'Life' Laments Miscegenation”, The Crisis, New York, jan. 1937, p. 19.

67 "Editorial of the Month", p. 19.

68 Harold Preece, “A Labor Boycott for Peace”, The Crisis, New York, fev. 1938, p. 43. 
Os anos 1940 verão esses esforços de aproximação com a realidade sul-americana se intensificarem. ${ }^{69}$ No entanto, a imagem do Brasil e de seu povo é ainda fantasiosa, na busca por contrastar a construção de um país mestiço (Brasil) em contraponto à segregação vigente nos Estados Unidos. Assim, por exemplo, o padre Antônio Vieira e o próprio d. João VI seriam mulatos. ${ }^{70}$ Tal tendência é reforçada, sem dúvida, e também explica a recepção entusiasta das ideias de Freyre e de Arthur Ramos, cujos livros repercutem intensamente nos escritos do historiador J. A. Rogers e do jornalista e professor James W. Ivy, do corpo de redação do The Crisis. Deste último, a resenha de O Estado nacional, de Francisco Campos, publicada em julho de 1941, é reveladora do quão freyriano tinha se tornado Ivy. Diz ele: “o Brasil, tal como os outros países latino-americanos, nunca foi uma democracia moderna", mas "uma coisa é certa, o atual regime Vargas certamente não é um regime fascista no sentido europeu do termo", ${ }^{71}$ ou seja, não é um estado racista. ${ }^{72}$

Do mesmo modo, as notícias das inclinações fascistas da FNB certamente chegaram aos negros norte-americanos. Lemos, por exemplo, no The Crisis de abril de 1942 que "dizem aos brasileiros que o pan-americanismo significaria escravidão para a raça negra naquele país. Em decorrência disso, sabe-se que um grande número de negros no Brasil filiou-se à organização fascista 'Ação Integralista". ${ }^{73}$ De certo modo, a imprensa negra americana está usando o racismo norte-americano para alertar seu governo sobre suas consequências internacionais, seja em termos de isolamento, seja em termos de perda de influência. O editorial de novembro de 1942 é explícito nesse sentido. Referindo-se a recentes

69 Pallares-Burke, O triunfo, pp. 272-276, nos ensina que no $77^{\circ}$ Congresso americano, em 1941, parlamentares como John M. Coffee já alertavam para o dano que o segregacionismo racial norte-americano causava nas relações dos Estados Unidos como os povos do terceiro mundo e, consequentemente, no combate ao nazismo e ao fascismo, em termos internacionais.

70 Ver, respectivamente, The Crisis, New York, jan. 1940, p. 9; e The Crisis, New York, maio 1940, p. 137.

71 James W. Ivy, "Brazilian Nationalism”, The Crisis, New York, jul. 1941, p. 235.

72 Sobre James W. Ivy, que editou o The Crisis entre 1950 e 1966, ler o obituário do The New York Times de 12 de abril de 1974, p. 34. "James W. Ivy Is Dead at 72; Edited 'Crisis' for N.A.A.C.P.”, <https://www.nytimes.com/1974/04/12/archives/james-w-ivy-is-dead-at-72-edited-crisis-for-naacp-anniversary.html $>$, acessado em 24/04/2020. 
linchamentos de negros no sul, observa: "Pode-se imaginar o que o Brasil, nosso novo e importante aliado, uma nação de $25 \%$ [sic] de pessoas de cor pelos padrões americanos, deve estar pensando". ${ }^{74}$

Ou seja, em 1944, tanto a opinião pública negra americana como os progressistas e liberais estão dispostos a acionar o Brasil como exemplo vivo e real de integração racial, em que pesem nossas tendências antidemocráticas, nosso alinhamento que privilegia o Estado americano em detrimento da comunidade negra norte-americana, e mesmo nossa resistência em aceitar imigrantes negros dos Estados Unidos. A reportagem de sete páginas, das quais cinco são repletas de fotos, publicada em fevereiro de 1944, com o título "Brasil: onde os negros estão integrados", é a melhor demonstração do esforço do Departamento de Estado, no período Pattee, em eleger o Brasil como um exemplo possível e realista de integração racial. ${ }^{75} \mathrm{Nela}$, entretanto, a expressão "democracia racial" não aparece nem como conceito norte-americano, nem, muito menos, como associada ao Brasil. A ideia de democracia nunca aparece associada ao Brasil no universo norte-americano.

\section{O Instituto Internacional de Estudos Afro-Americanos e a Afroamérica}

Retomemos a narrativa sobre os esforços pan-americanistas. O congresso de estudos afro-americanistas já referido fora pensado por Fernando Ortiz para realizar-se primeiramente em Havana, em 1941, financiado pelo American Council of Learned Societies. Diante de resistências encontradas naquela instituição, Ortiz tentará realizá-lo em Porto Príncipe, com o apoio de Pattee, mas o local também encontrará resistências por parte dos financiadores norte-americanos.

Para Ortiz, a resistência às suas iniciativas é orquestrada por Herskovits, com o apoio ativo da historiadora de Cuba pré-colonial, Irene Wright, com quem se desentendera em Havana e que ocupava agora um cargo no Departamento de Estado dos Estados Unidos. ${ }^{76}$ Já a postura de

74 "Editorials: Three for Hitler", The Crisis, nov. 1942, p. 343.

75 "Brazil: Where the Negroes are Integrated", The Crisis, fev. 1944, pp. 40-46.

76 Fernando Ortiz e Trinidad Pérez Valdés, Correspondencia 1940-1949. Havana: Fundación 
Herskovits, para Ortiz, se deveria em parte ao ressentimento deste com o prefácio que Malinowski escrevera para o seu Contrapunteo cubano del tabaco y el azúcar, contrapondo positivamente o seu conceito de "transculturação" ao conceito de "aculturação" usado por Herskovits. ${ }^{77}$

Pérez Veldés ${ }^{78}$ observa que, “em maio de 1943, [Ortiz] viajou para os Estados Unidos cumprindo um convite especial do governo daquele país. Naquela ocasião, visitou várias universidades e, em Nova York, foi convidado a participar da reunião do Comitê de Estudos Negros e do American Council of Learned Societies, presidido por Melville Herskovits, Ronald Young, Sterling Brown, Richard Pattee e outros. O objetivo dessa reunião foi a criação da Sociedade Interamericana de Estudos Negros, com uma publicação trimestral que levaria o nome de Afroamérica e para a qual Ortiz foi proposto como editor". Tal projeto também não sairá do papel.

Seis meses depois, em 20 de outubro de 1943, durante o Primeiro Congresso Demográfico Interamericano, Ortiz consegue o apoio unânime dos sociólogos e antropólogos presentes para criar o Instituto Internacional de Estudos Afro-Americanos, sediado na Universidad Nacional Autónoma de México (UNAM). O comitê executivo foi assim composto: diretor, Fernando Ortiz (Cuba); vice-diretor, Gonzalo Aguirre Beltrán (México); secretário, Renato de Mendonça (Brasil); ${ }^{79}$ tesoureiro, Daniel F. Rubín de la Borbolla (México); chefe de publicações, Jorge A. Vivó (México).

Ortiz se refere à reação furiosa de Herskovits à sua iniciativa e se defende em carta datada de 26 de janeiro de $1944:{ }^{80}$

Fernando Ortiz, 2016, p. 153.

77 Ortiz y Pérez Valdés, Correspondencia, p. 150.

78 Ortiz y Pérez Veldés, Correspondencia, p. 149.

79 Renato Mendonça, que havia apresentado trabalhos nos Congressos Afro-Brasileiros de Recife, em 1934, e de Salvador, em 1938, servia na ocasião na embaixada brasileira na Cidade do México. Ver Paulo Roberto de Almeida, "Renato Mendonça: um intelectual na diplomacia", Renato de Mendonça: Diplomacia, Ciência e Letras (Maceió, 2012). Era, portanto, um nome de confiança e de trânsito entre os intelectuais brasileiros. Pattee o procura tão logo chega ao México. Ver Carta de Pattee a Ramos, 27/11/1943, Biblioteca Nacional, Coleção Arthur Ramos, Correspondência, I-35,36,2083.

Ortiz y Pérez Veldés, Correspondencia, p. 165. 
Da minha parte, confesso que deixei Washington completamente pessimista, e o fato de não ter notícias em seis meses sobre o projetado Instituto, de que se tratou naquela cidade, me convenceu de que o projeto de Washington não teve êxito. Indubitavelmente, pesaram no meu convencimento as minhas experiências anteriores em relação às reuniões planejadas em Havana e Porto Príncipe, que evidentemente foram sabotadas por alguns interessados em não serem celebradas. Acredito que nos Estados Unidos há uma certa hostilidade atualmente a esse tipo de reunião e também acredito que a atmosfera do México é, ao contrário, muito favorável à ventilação de todos esses problemas das raças, pois lá não há preconceito no grau em que há em outros países.

Coincidência ou não, Pattee deixara o Departamento de Estado em 1943 para se estabelecer no México, onde ensinou como professor visitante na UNAM. O projeto de Ortiz, endossado por Pattee, era criar um instituto e uma revista que se afastassem do conflito de interesses cada vez maior entre Herskovits e os intelectuais negros norte-americanos, conflito esse que se centrava sobre uma questão: quem fala pelos negros norte-americanos? A postura de Ortiz fica muito clara nas cartas que envia a Jorge Vivó e a Fernando Romero. Ao mesmo tempo que tenta trazer os intelectuais negros norte-americanos para a revista Afroamérica, que tem na lista de seus colaboradores W. E. B. Du Bois, Franklin Frazier, Charles Johnson, Rayford Logan, Lorenzo Turner e outros, procura distanciar-se dos conflitos acadêmicos que minam o campo dos estudos raciais norte-americanos.

A Vivó escreve em 31 de janeiro de 1945: ${ }^{81}$

Não estou surpreso com as ideias estranhas que Herskovits tem sobre a revista. Eu acho muito boa a resposta que você deu a ele. Algumas pessoas me confirmam a ideia de que esse cavalheiro, sob uma camada de apoio entusiástico, segue um plano que certamente tende a sabotar qualquer instituição de sociedade afro-americana que não seja controlada por ele. Felizmente, ele não tem 
simpatia entre muitos antropólogos e sociólogos, especialmente os de cor. Além de outros fatores óbvios, isso sempre interrompeu a cooperação nesse tipo de trabalho para muitas pessoas nos Estados Unidos. Todos os problemas relacionados às questões afro-americanas têm ressonâncias muito extensas e sérias. Quanto a escrever para Herskovits, eu acho que seria contraproducente. Acredito que o sucesso do Instituto é demonstrar que ele pode continuar funcionando sem contar com pessoas envolvidas nos conflitos raciais nos Estados Unidos.

Mas Ortiz sabe também que há um terceiro grupo social envolvido nesse campo - o dos intelectuais latino-americanos, geralmente brancos, também muito próximos da máquina estatal de seus governos. O próprio Ortiz é um deles: é intrigante encontrarmos o médico cubano Israel Castellanos nesse instituto, por recomendação de Ortiz. Castellanos, antigo parceiro de Ortiz nos seus anos de estudos de frenologia, criminologia racial etc., continuou a trilhar esta linha racialista e eugenista e se tornara famoso em Cuba por participar do projeto de presídio-modelo durante a ditadura de Gerardo Machado. Mais tarde, durante a ditadura de Fulgencio Batista, havia rumores de que Castellanos colaborava com o FBI. ${ }^{\mathbf{2}}$ Renato Mendonça, do Brasil, e Fernando Botero, do Peru, por seu turno, pertenciam ao corpo diplomático de seus respectivos países.

A revista Afroamérica vem a público em 1945, com o volume 1, números 1 e 2, e tem um segundo volume em janeiro e julho de 1946. Arthur Ramos, Melville Herskovits, Alain Locke, Fernando Ortiz, Jorge

82 Kali Argyriadis e Maud Laëthier, "Anthropologie criminelle et pathologisation des pratiques religieuses d'origine africaine chez Justin Chrysostome Dorsainvil et Israel Castellanos", in Kali Argyriadis, Emma Gobin, Maud Laëthier, Niurka Núñez González, Histoire comparée des anthropologies cubaine et haïtienne: une anthologie (1880-1959), (Montreal: CIDIHCA, 2020), no prelo. Escrevem as autoras: "Sob a ditadura de Gerardo Machado, ele colaborou no Departamento de Moralização (uma agência de propaganda do Estado) e fichou sistematicamente detidos e pessoas loucas. Ele também propôs um plano para a reforma do sistema penal cubano, participando da organização do Presídio Modelo, um centro penitenciário onde foram testadas técnicas eugênicas que levaram à morte de mais de 500 prisioneiros [...]. Em 1928, ele publicou em dois volumes La delincuencia femenina em Cuba, que lhe rendeu o Prêmio Lombroso, e no qual defendeu a esterilização sistemática de prostitutas e outras mulheres delinquentes. Entre as décadas de 1930 e 1950, [Castallanos] publicou quase mil artigos, compilados e/ou reimpressos em várias coleções, incluindo Medicina legal et criminología afrocubanas (1937). Muito próximo de John Edgar Hoover, fundador do FBI nos Estados Unidos, ele continuou suas atividades de fichamento para o governo de Fulgencio Batista". 
Vivó e Jean Price-Mars formam o seu comitê de redação. São os dois únicos volumes. Em 1946, sem financiamento e com boa parte da equipe mexicana tendo se deslocado para estudar nos Estados Unidos, o Instituto já não existe. ${ }^{83} \mathrm{~A}$ estadia de Pattee no México também será curta: no ano seguinte já estará de volta aos Estados Unidos. Em carta a Ramos, escreve em 17 de fevereiro de 1945: "eu deixei o México em dezembro [de 1944] para passar alguns meses em Porto Rico". ${ }^{84}$

Na Afroamérica não há uma só menção, em todas as suas páginas, em seus dois volumes, à "democracia racial". A influência intelectual de Ramos ou Freyre na revista é praticamente nula. Muitos autores negros norte-americanos têm seus livros resenhados, assim como os brasileiros, cubanos e outros latino-americanos, mas prevalecem entre os artigos publicados a agenda de Herskovits de estudos dos africanismos nas Américas e a estratégia de política antirracista desenhada nos Estados Unidos a partir de An American Dilemma, de Gunnar Myrdal, e pelos intelectuais negros em What the Negro Wants, editado por Rayford Logan. ${ }^{85}$ An American Dilemma foi fruto de uma grande coalisão progressista, financiada pela Carnegie Corporation of New York, que envolvia todos os setores acadêmicos norte-americanos engajados na luta antirracista; What the Negro Wants é uma importante coletânea de textos de eminentes lideranças negras que buscavam retomar e consolidar o protagonismo político naquela luta.

A breve existência da revista Afroamérica no México parece indicar uma pista de investigação que já sugerimos anteriormente. Nem outros latino-americanos nem norte-americanos tiveram muito interesse em desenvolver as ideias de Freyre e Ramos. Os primeiros pela centralidade do ideal de nação mestiça prevalecente em seus países, em que os negros são preteridos em relação aos indígenas; os últimos diante

83 Kali Argyriadis e Nahayeilli Juarez Huet, "L'anti-racisme au fondement de la création de l'Instituto International de Estudios Afroamericanos (Mexico, 1943-1946)", L'anti-racisme entre science et politique: de l'Amérique Latine à l'UNESCO (1920-1960) (Nice, 2019).

84 Carta de Pattee a Ramos, 17/2/1945, Biblioteca Nacional, Coleção Arthur Ramos, Correspondência, I-35,36,2086.

85 Rayford W. Logan, What the Negro Wants, Chapel Hill: The University of North Carolina Press, 1944. 
da irreversibilidade política das raças (brancos e negros) e do credo na democracia americana. Essas crenças nacionais parecem inabaláveis.

Ademais, é certo que o interesse de Pattee pelo tema afro-americanista e antirracista não era o único nem talvez o mais importante que o ocupava no Departamento de Estado. Assim como a democracia racial brasileira, era apenas parte de um interesse mais abrangente de Pattee em promover o intercâmbio pan-americano. Tendo realizado seus estudos de pós-graduação e defendido o mestrado na Universidade Católica de Washington sobre a história colonial do Equador, seu conhecimento sobre esse país pode ser documentado por uma carta aberta publicada pelo humanista e jesuíta equatoriano Aurelio Espinosa Polit, na Revista Iberoamericana, a respeito de sua viagem aos Estados Unidos: "Tendo visitado 12 grandes universidades em três meses, fora de outras instituições de ensino superior, e lidado exclusivamente com estudiosos, encontrei apenas duas pessoas com quem pude ter uma conversa inteligente sobre o Equador, Dr. Ricardo Pattee, do Departamento de Estado, e Prof. Rippy da Universidade de Chicago". ${ }^{86}$ Aurélio Espinosa Polit fundará um pouco mais tarde, em 1946, a Pontificia Universidad Católica del Ecuador (PUCE), na qual Pattee dará aulas como visitante.

Exemplo ainda mais claro da missão pan-americanista de Pattee encontra-se na revista The Americas:

Em uma celebração pan-americana de dois dias na Universidade de St. John, Brooklyn, o Dr. Richard Pattee, da National Catholic Welfare Conference, e o Rev. R. A. McGowan, diretor do Departamento de Ação Social da N.C.W.C., foram os principais oradores. Representantes de vinte países da América Latina e delegações de 180 faculdades, universidades e escolas secundárias participaram da celebração patrocinada pelo Escritório de Assuntos Interamericanos do Departamento de Estado dos EUA. O Dr. Pattee recebeu a medalha de ouro Pi Alpha Sigma, concedida anualmente pela fraternidade de St. John ao americano que

86 Aurelio Espinosa Polit, “S. J. Carta Abierta”, Revista Iberoamericana, v. 6, n. 11 (1943), pp. 21-22. 
mais se destacou na promoção de relações amistosas entre os povos do Hemisfério Ocidental. ${ }^{87}$

A essa altura, em 1946, Pattee já tinha voltado aos Estados Unidos e lecionava na Universidade Católica de Washington. Na mesma carta a Ramos, citada acima, ele havia demonstrado interesse em voltar a excursionar pela América do Sul, "pela costa do Pacífico [...] e mais tarde [pel]o Brasil e Uruguai". ${ }^{8}$

\section{A revista Quilombo e o Teatro Experimental do Negro}

Será no Brasil que, ainda nos anos 1940, a noção de "democracia racial", tal como definida por Freyre e Ramos, ganhará acolhimento integral por parte das lideranças negras, dos intelectuais progressistas e da grande imprensa, passando a ser considerada a forma brasileira, por excelência, do antirracismo. ${ }^{89}$ Isso muito antes de ganhar o mundo pelas publicações do projeto da Unesco, entendimento que continuará pelo menos até 1964, quando começou a ser denunciada como logro por Abdias Nascimento, ${ }^{90}$ ou mito, por Florestan Fernandes. ${ }^{91}$

Tome-se, como exemplo, a revista Quilombo, que foi dirigida por Abdias Nascimento e publicada no Rio de Janeiro entre 1948 e 1950. Quilombo teve em todos os seus números uma coluna intitulada "Democracia Racial”, onde escreveram Gilberto Freyre, Arthur Ramos, Paul Vanorden Shaw - representante da Organização das Nações Unidas no Brasil -, o senador Hamilton Nogueira, o compositor Orestes Barbosa, Estanislau Fischlowitz, Ralph Bunche, Roger Bastide e o escritor Murilo Mendes. Lidos em conjunto, esses textos demonstram a mais completa confusão entre mestiçagem, ausência de linha de cor, protestos por

87 "Inter-American Notes", The Americas, v. 3, n. 1 (1946), p. 115.

88 Carta de Pattee a Ramos, 17/2/1945, op. cit.

89 Ver Antonio Sérgio Alfredo Guimarães e Márcio Macedo, "Diário Trabalhista e democracia racial negra dos anos 1940", Dados, v. 51, n. 1 (2008), pp. 143-182.

90 Abdias Nascimento, "Depoimento", Cadernos Brasileiros, n. 47 (1968), p. 22.

91 Octávio Ianni, As metamorfoses do escravo, São Paulo: Difusão Europeia do Livro, 1962, p. 265. 
igualdade de direitos e de oportunidades entre brancos e negros naquele espaço de Quilombo.

Ao longo de seus dez números, prevaleceu em Quilombo a visão expressada por lideranças negras como Guerreiro Ramos:

O Brasil deve assumir no mundo a liderança da política de democracia racial. Porque é o único país do orbe que oferece uma solução satisfatória do problema racial. Com respeito aos homens de cor, oferece-lhes a sociedade brasileira praticamente todas as franquias. E se há um problema dos homens de cor em nosso país, ele consiste eminentemente em exercitá-los, pela cultura e pela educação, para usar aquelas franquias. ${ }^{92}$

Ou Abdias Nascimento:

Observamos que a larga miscigenação praticada como imperativo de nossa formação histórica, desde o início da colonização do Brasil, está se transformando, por inspiração e imposição das últimas conquistas da biologia, da antropologia e da sociologia, numa bem delineada doutrina de democracia racial, a servir de lição e modelo para outros povos de formação étnica complexa, conforme é o nosso caso. ${ }^{93}$

A consolidação do antirracismo construído em torno do ideal de democracia racial, entretanto, parece ter ocorrido na capital da República, Rio de Janeiro, mas se restringido, em seu sentido pleno, muito provavelmente, a áreas onde a interação entre intelectuais negros e brancos era maior. Em estados como São Paulo e muito provavelmente mais ao sul, ou seja, nas áreas de grande e recente imigração europeia, não encontramos essas manifestações de aderência integral por parte dos intelectuais negros. Por exemplo, o jornal Alvorada, onde Correia Leite escrevia regularmente, menciona apenas uma vez, entre 1945 e 1948, a expressão "democracia racial", e ainda assim em tom de denúncia do

92 Alberto Guerreiro Ramos, “Apresentando a negritude”, Quilombo, n. 10 (1950), p. 1.

93 Abdias Nascimento, "Discurso pronunciado na Associação Brasileira de Imprensa, em 26-081950”, Quilombo, n. 10 (1950), p. 1. 
seu caráter postiço e artificial. ${ }^{94}$ Em São Paulo, os negros continuaram a arregimentar-se quase que inteiramente em torno das denúncias sobre os preconceitos raciais e do protesto contra o esquecimento a que foram relegados pela República.

\section{A democracia racial e seus desdobramentos na África portuguesa}

Em verdade, a gradual e contínua aproximação de intelectuais negros brasileiros com os movimentos anticolonialistas africanos cindiu também gradualmente a frente antirracista brasileira que ainda apostava na democracia racial como bandeira de luta, no começo de 1960. Isso ocorreu principalmente à medida que Freyre passou a defender o colonialismo português na África, já nos anos 1950, e ampliou sua compreensão das relações raciais brasileiras com a teoria do luso-tropicalismo, fartamente usada pelo governo Salazar na África. ${ }^{95}$ Freyre em diversas oportunidades criticara a construção de uma identidade negra no Brasil, até que, depois do golpe militar de 1964, aderiu completamente a uma agenda em defesa daquele colonialismo e de apoio ao novo regime político autoritário brasileiro. Quanto a Ramos, este morreu no final de 1949, negociando o que será depois o projeto Unesco de relações raciais. ${ }^{96}$

94 “[...] relegando para segundo plano um dever que, 'esquecido' nos momentos finais da Monarquia, dia a dia se torna mais 'esquecido' na República. É mais cômodo deixar que a prata da casa, o construtor da riqueza nacional, o perpétuo defensor da integridade da pátria se estiole no mais inglório dos fins, consumido pelos excessos, aviltado no moral, minado na robustez. É que, apesar das muitas repetidas declarações platônicas de nossa democracia racial, teimamos agasalhar dogmas anacrônicos e preconceitos carcomidos". Raul J. Amaral, "Símbolo de boa vontade", Alvorada, dez. 1946, p. 5.

95 Gilberto Freyre, Integração portuguesa nos trópicos, Lisboa: Junta de Investigações do Ultramar, 1958; Gilberto Freyre, Integração das raças autóctones e de culturas diferentes da europeia na comunidade luso-tropical: aspectos gerais de um processo, Lisboa: Congresso Internacional de História dos Descobrimentos, 1961; Gilberto Freyre, O Brasil em face das Áfricas negras e mestiças, Rio de Janeiro: Federação das Associações Portuguesas, 1962.

96 Marcos Chor Maio, "UNESCO and the Study of Race Relations in Brazil: National or Regional Issue?", Latin American Research Review, v. 36, n. 2 (2001), pp. 118-136; Marcos Chor Maio, "Florestan Fernandes, Oracy Nogueira, and the UNESCO Project on Race Relations in São Paulo", Latin American Perspectives, v. 38, n. 3 (2011), pp. 136-149; Elizabeth Cunin, "L'UNESCO à l'origine de l'antiracisme? Ethnographie historique de la question raciale (1946-1952)", L'anti-racisme entre science et politique: de l'Amérique Latine à l'UNESCO (1920-1960) (Nice, 2019). 
Pattee, no final dos anos 1940, se estabelece na Bélgica, onde volta a fazer estudos doutorais na Universidade Católica de Louvain, uma indicação de que talvez não tenha completado seu grau em Porto Rico. Nos anos 1950, o encontramos ensinando na Universidade de Friburgo, na Suíça. Seu interesse muda então da América Latina para a Europa e África. Em 1950, escreve para Ramos, sem saber que o amigo havia morrido meses antes, para comunicar que tinha se estabelecido na Suíça, e estava interessado em promover intercâmbios acadêmicos entre Friburgo e universidades brasileiras. Em termos intelectuais, vemo-lo, primeiro, interessado pela Espanha e, finalmente, pela África de expressão portuguesa e inglesa. É quando passa a ter, como Freyre, destacada atuação política em defesa do colonialismo português na África. A Agência Geral do Ultramar publica, em 1959, a tradução do seu livro Portugal and the Portuguese World, ao qual foi conferido, em 1958, o prêmio Camões. Em 1960, recebeu o título de doutor honoris causa por Coimbra, dois anos antes, portanto, de Gilberto Freyre. Muito interessante é que seu padrinho de doutoramento em Coimbra tenha sido o embaixador americano Charles Burke Elbrick, que servirá depois no Brasil, onde será sequestrado pela guerrilha urbana.

Mais interessante ainda é aprendermos que o doutor Pattee, àquela altura, talvez não tivesse ainda o título de doutor, apesar de sua passagem pela formação doutoral em Porto Rico e em Louvain. Pelo menos é o que sugere Martins em seu Discurso no doutoramento solene do doutor Richard Pattee pela Faculdade de Letras da Universidade de Coimbra. ${ }^{97}$ Ou teria sido esse o seu terceiro título? Nessa época, nos anos 1960, já está radicado no Canadá, onde ensinava na Universidade Laval, no Quebec, também católica. Muitas das referências que encontramos hoje a seu nome, portanto, tratam-no como "historiador canadense", ainda que outras continuem tratando-o como porto-riquenho ou norte-americano.

O fato é que as ideias de Freyre penetraram a África colonial portuguesa e, nos anos 1970, o governo militar brasileiro redirecionou sua 
diplomacia para construir junto aos africanos a imagem do país como uma democracia racial em moldes freyrianos. ${ }^{98} \mathrm{Tal}$ esforço de popularização da democracia racial na África não deixou de vingar, ${ }^{99}$ ainda que denunciado pelos movimentos de independência africanos e pelos movimentos negros brasileiros de apoio às lutas de libertação.

\section{À guisa de conclusão}

As ideias às vezes antecedem aos nomes que no presente as denominam, outras vezes thes sucedem, quando novas ideias tomam de empréstimo velhos nomes. No caso da "democracia racial", tal como a conhecemos no Brasil do século XX, ela foi usada em pelos menos três sentidos distintos: foi ideal de igualdade de direitos entre raças numa democracia política, à maneira norte-americana; teve o sentido de hierarquia de raças numa cidadania limitada e hierarquizada, mas não ditatorial, em Menotti Del Picchia e Cassiano Ricardo; e significou, enfim, trânsito, mescla, intimidade e convivência entre raças, tendo nessa acepção o nome de "democracia social" em Freyre, que Ramos alterou para "democracia racial".

Em política internacional, a "democracia racial" foi apresentada durante a Segunda Grande Guerra como antirracismo, em contraste com o racismo nazista, fascista ou colonialista; enquanto, no contexto da Guerra Fria, serviu à permanência do colonialismo português na África, ao mesmo tempo que era usada, no Brasil, para contrastar as práticas racistas nos Estados Unidos ou na África do Sul com as relações raciais brasileiras.

No plano da política doméstica dos anos 1960 e 1970, a "democracia racial" foi extensivamente usada para invisibilizar as desigualdades raciais brasileiras e o nosso racismo mais institucional e estrutural que

98 Ver sobre a política brasileira na África, principalmente em Angola: Jerry Dávila, Hotel Trópico: Brazil and the Challenge of African Decolonization, 1950-1980, Durham: Duke University Press, 2010; Gisele Christini de Sousa Lobato, "O Brasil e a independência de Angola (1975): política externa oficial e diplomacia militar paralela" (Dissertação de Mestrado, Instituto Universitário de Lisboa, 2015).

99 Em 2006, o presidente de Cabo Verde, em visita a Salvador, jactou-se de que seu povo vivia em uma democracia racial. Ver: "Presidente de Cabo Verde defende o fortalecimento da democracia racial para advogados afrodescendentes", Fundação Cultural Palmares, 14/07/2006, $<$ http://www.palmares.gov.br/?p=1545>, acessado em 24/04/2020. 
doutrinário. No entanto, não há que se negar sua eficácia em inibir manifestações mais grosseiras de racismo. Esse uso doméstico brasileiro acabou por se espalhar por toda a América Latina, principalmente em países de formações raciais negras importantes, como Cuba, ${ }^{100}$ Colômbia ${ }^{101} \mathrm{e}$ Venezuela ${ }^{102}$ quando protestos negros ganharam a cena política da região, revertendo a invisibilidade criada pelo imaginário de nações mestiças.

Os usos e os sentidos da democracia racial, portanto, tiveram diferentes agentes, com interesses políticos também diferentes. Lembro apenas alguns dos protagonistas citados neste texto: os intelectuais modernistas brasileiros, os africanistas latino-americanos, os intelectuais negros norte-americanos e brasileiros, o Itamaraty, o Departamento de Estado norte-americano, o colonialismo português. Em certas ocasiões, tais interesses convergiram entre si; em outras divergiram. A polissemia, ainda que dificulte em muito a análise correta de cada um desses usos e dos interesses que expressam, é, em última análise, a única trilha que podemos seguir.

Muito difícil e improvável, por exemplo, é dizer que um agente tão ativo quanto Richard Pattee tenha tido uma mesma motivação ou representasse uma única instituição durante seus anos de colaboração com os intelectuais do Harlem, com os intelectuais brasileiros e latino-americanos e com os colonialistas portugueses. Sua trajetória nesses espaços e tempos sociais nos ajuda, entretanto, a compreender o modo como o antirracismo foi acionado e manipulado durante esses anos e nesses lugares. E essa compreensão é a que vale afinal.

A história da democracia racial é parte do fracasso das classes dominantes de origem portuguesa e espanhola de integrar social e politicamente as populações africanas trazidas e escravizadas no Novo Mundo. Mas é também parte do fracasso das elites latino-americanas de consolidar regimes democráticos e não racistas. A Herrenvolk democracy ${ }^{103}$ do sul

100 Alejandro de la Fuente, A Nation for All: Race, Inequality, and Politics in Twentieth-Century Cuba, Chapel Hill: University of North Carolina Press, 2001.

101 Peter Wade, Blackness and Race Mixture: the Dynamics of Racial Identity in Colombia, Baltimore: Johns Hopkins University Press, 1993.

102 Winthrop Wright, Café con Leche: Race, Class, and National Image in Venezuela, Austin: University of Texas Press, 1990.

103 Richard J. Ellis, "Legitimating Slavery in the Old South: The Effect of Political Institutions 
americano se esgotara com a explosão do racismo na Europa dos anos 1920 e o Holocausto que se seguiu na Segunda Grande Guerra. Novas ideologias raciais e novas políticas de integração deveriam ser imaginadas e implementadas tanto na Europa quanto na América. Nos Estados Unidos, o desenvolvimento das ciências sociais desde Franz Boas, na Universidade de Columbia, e de Robert Park, Louis Wirth, Ernest Burgess e Everett Hughes, na Universidade de Chicago, apontava um caminho possível de antirracismo, principalmente porque estes possibilitaram o diálogo com a intelectualidade negra e acadêmica que se formara nos anos 1910 e 1920 e atuava nas universidades do sul - Fisk, Howard, Atlanta. Essa articulação, mediada, muitas vezes, pelo Departamento de Estado americano, possibilitou que intelectuais latino-americanos, principalmente de Cuba, do Haiti, do Brasil e do México, fossem incluídos nessa empreitada de imaginação antirracista. A rede que Herskovits, Ortiz, Price-Mars e Ramos haviam formado nos estudos africanistas seria apenas um embrião dessa nova articulação. A esta se somou, logo em seguida, a iniciativa da Unesco, na qual o Brasil, através de Arthur Ramos e Alfred Métraux, teve um papel decisivo. É a partir desta última iniciativa que a noção de democracia racial ganha penetração internacional, associando mestiçagem com mobilidade social e igualdade de oportunidades de vida para todas as raças de uma sociedade política.

Não foi encontrado um caminho único para a igualdade racial, como sabemos. A luta pelos direitos civis nos Estados Unidos pavimentou o caminho para a igualdade política e social dos negros norte-americanos, enquanto a democracia racial possibilitou por um breve período uma nova forma de acomodação pacífica dos negros brasileiros, depois apropriada também muito brevemente por outros países latino-americanos.

Recebido em 10/01/2019 e aceito em 19/10/2019

on Ideology", Studies in American Political Development, v. 5, n. 2 (1991), pp. 340-351. 


\title{
Resumo
}

Neste artigo, revisito a história da democracia racial enquanto ideologia racial, cunhada entre os anos 1930 e 1940. Procuro acompanhar a negociação intelectual que ocorreu entre diversos intelectuais brancos e negros, no Brasil e nos Estados Unidos, a partir da rede tecida entre Herskovits, Ortiz, Price-Mars e Ramos, e daquela outra que envolvia os cientistas sociais das universidades de Chicago, Atlanta, Fisk e Howard, estudando as formas de integração do negro à sociedade americana. Tais conexões foram absorvidas no esforço de guerra do Departamento de Estado americano, antes e durante a guerra, para aproximar-se dos países da América Latina, ao tempo que procurava uma nova política racial doméstica que substituísse a Herrenvolk democracy, cunhada no sul americano.

Palavras-chave: democracia racial - Brasil - Estados Unidos - América Latina.

\begin{abstract}
In this article, I revisit the history of racial democracy as a racial ideology coined between the 1930s and 1940s. I follow the intellectual negotiation that took place between various White and Black intellectuals in Brazil and the United States, starting from the network woven between Herskovits, Ortiz, Price-Mars and Ramos, to another one that involved social scientists from the universities of Chicago, Atlanta, Fisk, and Howard, studying the difficult integration of the African-American population into American society. Such intellectual networks were absorbed in the US Department of State's pre-war and wartime efforts to reach out and include Latin American countries into its influence area while seeking a new domestic racial policy that would replace the Herrenvolk democracy coined in the Deep South.
\end{abstract}

Keywords: racial democracy - Brazil - United States - Latin America. 